2. Токарева В.О. Умови охороноздатності об'єктів авторського права / В.О. Токарева // Приватне та публічне право. 2019. № 3. С. 39-43.

3. Харитонова О.І. Літературні та наукові твори як об'єкти авторських прав / O.I. Харитонова // Часопис иивілістики. 2016. Вип. 21. С. 100-104.

4. Ионас В.Я. Произведения творчества в гражданском праве. М., 1972. с. 56.

5. Сергеев А.П. Право интеллектуальной собственности в РФ. М., 2005. с. 160.

6. Елисеев В.И. Право на переработку произведения по российскому законодательству / В.И. Елисеев // Вестник Московского университета. 2017. № 1 (Серія 11). С. 93-104.

7. Гаврилов Э.П. Право интеллектуальной собственности. Авторское право и смежные права. ХХІ век. М. : Юрсервитум, 2016.

8. Демьяненко Е.В. К вопросу о правовой охране производных произведений / Е.В. Демьяненко, А.В. Шпак // Юристь - Правоведъ. 2019. № 1(88). С. 25-29.

9. Написанная на основе фотографии картина не нарушает авторские права фотографа. URL: https://www.dekuzu.com/ru/2018/04/paintings-based-on-photo-whether-adaptation-orindependent-work.html.

10. Люк Б. Решение суда поперек истории искусства, 16 апреля 2015 год. URL: http://www.theartnewspaper.ru/posts/1542/.

11. Roger vs Koons: A FEUD over a photograph URL: https://www.iprconference.com/blog/ roger-vs-koons-a-feud-over-a-photograph/.

УДК $347.73+342.951$

DOI https://doi.org/10.32844/2618-1258.2019.6.6

ФЕСЕНКО О.М.

\title{
ІНВЕСТИЦІї ТА ІНВЕСТИЦІЙНА ДІЯЛЬНІСТЬ ЯК ОБ'СКТ ПРАВОВОГО ЗАХИСТУ
}

\begin{abstract}
Метою статті є дослідження поглядів на сутність інвестицій та інвестиційної діяльності як об'єкта правового захисту. Так, у статті проаналізовано різні підходи вітчизняних та зарубіжних науковців щодо визначення сутності понять «інвестиції» та «інвестиційна діяльність», визначено суперечні та проблемні моменти в них, здійснено аналіз даних категорій як об'єкта адміністративно-правового захисту. 3'ясовано, що інвестиціями можуть бути: кошти, цільові банківські вклади, паї, акції та інші цінні папери (крім векселів); рухоме та нерухоме майно (будинки, споруди, устаткування та інші матеріальні цінності); майнові права інтелектуальної власності; сукупність технічних, технологічних, комерційних та інших знань, оформлених у вигляді технічної документації, навиків та виробничого досвіду, необхідних для організації того чи іншого виду виробництва, але не запатентованих; права користування землею, водою, ресурсами, будинками, спорудами, обладнанням, а також інші майнові права та інші цінності. Наголошено, що в повсякденній практиці під категорією «інвестиції» розуміється сукупність різних способів капіталовкладення у приватному секторі економіки та використання доходів із метою подальшого збільшення, придбання засобів виробництва. Зроблено висновок, що інвестиційній діяльності держави притаманні основні ознаки фінансової діяльності, що зумовлює можливість ії характеристики як складової частини механізму соціального управління, спрямованого на задоволення публічних інтересів, та свідчить про можливість іiі регулювання нормами фінансового право. У чинному законодавстві відсутні визначення понять «інвестиція» та «інвестиційна діяльність» як об'єктів адміністративно-правового захисту, а отже, повною мірою не
\end{abstract}

публічного права) 
розкривається сутність правового захисту інвестицій та інвестиційної діяльності. Отже, правовий захист інвестицій являє собою гарантовану державою на основі законодавства про інвестиційну діяльність забезпеченість інвесторам, у тому числі іноземним, рівноправних умов діяльності, що виключають застосування заходів дискримінаційного характеру, які могли б перешкоджати управлінню та розпорядженню інвестиціями.

Ключові слова: адміністративно-правовий захист, захист прав інвесторів, інвестииії, інвестииійна діяльність.

The aim of the article is to study the views on the essence of investment and investment activity as an object of legal protection. Thus, the article analyzes the different approaches of domestic and foreign scholars to determine the essence of the concepts of "investment" and "investment activity", identifies contradictory and problematic issues in them, analyzes these categories as an object of administrative and legal protection. It was found that investments can be funds, targeted bank deposits, shares, stocks and other securities (except promissory notes); movable and immovable property (buildings, structures, equipment and other tangible assets); intellectual property rights; a set of technical, technological, commercial and other knowledge, designed in the form of technical documentation, skills and production experience necessary for the organization of a particular type of production, but not patented; rights to use land, water, resources, buildings, structures, equipment, as well as other property rights and other values. It is emphasized that in everyday practice, the category of investment means a set of different ways of investing in the private sector of the economy and the use of income to further increase the acquisition of means of production. It is concluded that the investment activity of the state has the main features of financial activity, which determines the possibility of its characteristics as part of the mechanism of social governance aimed at satisfying public interests, and indicates the possibility of its regulation by financial law. The current legislation does not define the concepts of investment and investment activities as objects of administrative and legal protection, and, therefore, does not fully disclose the essence of legal protection of investments and investment activities. Thus, the legal protection of investments is a state-guaranteed on the basis of legislation on investment activities providing investors, including foreign ones, with equal conditions of activity that exclude the application of discriminatory measures that could impede the management and disposal of investments.

Key words: administrative and legal protection, protection of investors rights, investments, investment activity.

Вступ. В умовах обмеженості інвестиційних ресурсів національної економіки України об'єктивно висувається вимога більш опрацьованого підходу до процесу їх формування та оптимального використання. Національні інтереси України потребують підтримки вітчизняних інвесторів та вироблення єдиної лінії правового захисту держави й інших учасників інвестиційної діяльності. Адміністративно-правовий захист інвестицій та інвестиційної діяльності турбує всю світову спільноту. Звідси й виникає необхідність вироблення ефективного механізму захисту інвестицій та інвестиційної діяльності, який буде сприяти зростанню суспільного добробуту, реалізації інновацій у процесі здійснення інвестиційної діяльності через функцію саморегулювання та стимулюватиме вкладення іноземних інвестицій у національну економіку України.

Аналіз останніх досліджень і публікацій. Вагомий внесок у дослідження сутності інвестицій та інвестиційної діяльності зробили такі сучасні науковці: В. Авер'янов, О. Вінник, Л. Воронова, О. Горбунова, О. Грачова, Є. Додін, Н. Ісаєва, М. Карасьова, С. Ківалов, М. Кучерявенко, I. Пахомов, Л. Савченко, С. Ципкін, В. Чернадчук та інші. Однак, незважаючи на численні доробки вчених, потребують вирішення питання визначення та уточнення понятійно-категоріального апарату дослідження інвестицій та інвестиційної діяльності як об’єкта правового захисту.

Постановка завдання. Метою статті є дослідження поглядів на сутність інвестицій та інвестиційної діяльності як об’єкта правового захисту.

Результати дослідження. Одним із найважливіших факторів, що впливає на інвестиційний клімат будь-якої держави, виступає наявна система законодавства. Дана система визначає 
національний правовий режим інвестиційної діяльності та регламентує принципи й механізм взаємовідносин інвесторів із державними органами - $з$ однієї сторони, а також з іншими учасниками економічних відносин та суб'єктами господарювання - з іншої.

Треба констатувати, що економіка України залежить від імпорту товарів і технологій, i якщо найближчим часом не відбудеться корінних змін, то це може призвести до того, що Україну на світовій арені будуть сприймати тільки як сировинну державу з неінноваційною системою. Для недопущення подібної ситуації необхідна істотна зміна механізмів економічного зростання України, одним із яких має стати масштабна переорієнтація інвестицій в інноваційну сферу, значною мірою це залежить від повноти та ступеня досконалості нормативно-правової бази.

Саме тому необхідність залучення додаткових коштів для розв'язання економічних проблем спонукає законодавця шукати оптимальні варіанти для покращення інвестиційного клімату в державі. Проте інвестори не мають бажання вкладати кошти у країни, в яких належним чином не забезпечено захист їхніх прав та законних інтересів [1, с. 5]. Таким чином, забезпечення належного адміністративно-правового захисту інвестицій та прав інвесторів в Україні потребує першочергового вирішення. Із цього приводу К.Г. Булатов зазначає, що необхідність докорінного оновлення методології формування i, відповідно, теоретичного аналізу адміністративно-правового захисту пояснюється також комплексом соціальних, економічних і правових причин [2, с. 11].

Одна з основних проблем, яка призводить до колізійної ситуації в українському законодавстві та інших нормативно-правових актах, пов'язана з розбіжностями в застосуванні тих чи інших термінів та їхніх визначень. Отже, виходячи з вищевикладеного, вже сьогодні варто формувати національний єдиний нормативно-правовий простір і забезпечувати однозначність застосування юридичної, економічної та фінансової термінології і в межах окремих нормативно-правових актів, і в рамках усього галузевого законодавства. Формуючи загальноправову міжгалузеву і галузеву термінологію, слід установлювати, як стверджує О.Б. Олійник [3, с. 28], і неухильно дотримуватися приписів щодо застосування однозначності юридичних, економічних та фінансових термінів, а також вимог до їхньої понятійної точності та зрозумілості. Як справедливо зауважує Ю.Ф. Прадід у монографії [4], законодавець, розробник будь-якого нормативно-правового акта, положення, інструкції чи стандарту має дати юридичному, економічному терміну «одне єдине визначення, включаючи в нього всі істотні, на його погляд, ознаки, тобто такі, що мають регулятивний характер, мають правове значення» [3, с. 28; 4].

Варто зазначити, що якщо в гуманітарній сфері наявність багатозначних висловів допустима й вони характеризують багатство української мови, то в суспільних науках така ситуація може призвести до негативних наслідків. А тому постійно треба вживати заходів щодо вилучення таких термінів, потрібно запровадити правові механізми для упередження цього явища і в економічних, фінансових та юридичних документах уживати тільки чітко визначені терміни, які мають однозначне та зрозуміле трактування. А для цього, тобто для запобігання появі та застосуванню багатозначних, неточних і незрозумілих термінів, доцільно ухвалити спеціальні стандарти або ж закони, які б регламентували використання термінів у законодавчих і нормативно-правових актах, а також різного роду документах, які регулюють діяльність фінансових та юридичних інститутів. У таких документах до стилістики і мови, застосування термінології варто висувати вимоги однозначності, точності та зрозумілості вживаної термінології та всього термінологічно-понятійного апарату, який використовується в теоретичній і практичній діяльності правознавців, економістів, фінансистів та інших фахівців [5; 6, с. 207-210; 7, с. 46-48].

Необхідність формування єдиної понятійної бази інвестицій зумовила потребу в однаковому формулюванні таких ключових понять, як «інвестиція», «іноземна інвестиція», «державна інвестиція», «інвестиційна діяльність», «інвестиційна політика» тощо. Сьогодні ця потреба не задоволена. Ні вітчизняною, ні закордонною правовою наукою не запропоновано єдиного формулювання цих термінів.

Разом із тим необхідно відзначити, що хоча монографічних досліджень сутності інвестиційного права як правової освіти в сучасній юридичній науці не проводилося, в літературі висловлюються самі різні думки про місце інвестиційного права в системі права. У силу відомої «модності» в останні роки теорії комплексних галузей права нерідко наголошується, що інвестиційне право, та й все фінансове право взагалі виступає комплексною галуззю права (позиція про комплексний характер фінансового права вперше була висунута ще за радянських часів I.С. Гуревичем [8], у сучасній українській науці даної точки зору дотримуються М.П. Кучерявенко, М.Г. Волощук, Т.О. Карабін, М.В. Менджул [9; 10]). Крім того, існує думка про те, що інвестиційне право - не галузь права, а комплексна галузь законодавства, що об'єднує норми різної галузе- 
вої приналежності, тому інвестиційне право не має самостійного предмета та методу правового регулювання і не може бути визнане як самостійна галузь права [11, с. 151]. Із цим твердженням не згоден О.М. Вінник, зазначаючи, що, перш ніж робити висновок про місце інвестиційного права в системі права, слід уважно вивчати питання про визначення сутності самої системи права як складного системного формування [12, с. 11]. Із цього приводу існує два підходи: концепція «подвоєння структури права» $[13$, с. 22,27$]$ та концепція «одноплощинної структури права» $[14 ; 15 ; 16]$. Аналіз обох концепцій дозволяє вченому прийти до висновку про те, що і тими, й іншими визнається наявність комплексних правових норм у системі права і в системі законодавства. Тим більше, що практично неможливо виявити відмінності між такими поняттями, як «комплексні галузі» та «комплексні правові спільності». Це ж відноситься і до співвідношення системи права та системи законодавства, відмінності між якими не здатні здійснити істотного впливу на формування галузей права. Тому ми згодні з тим, що набагато логічніше виглядає конструкція наявності вторинної, яка нашаровується на основні галузі, структури. Вірним є й уявлення про те, що для формування комплексної галузі права необхідна наявність комплексного акта, що зачіпає цілі сфери соціального життя або їх ділянки. Наприклад, Гуткевич С.О. робить висновок про те, що інвестиційне право являє собою цілісне правове утворення, яке відрізняється єдністю складових частин його інститутів, що об'єднує норми різних галузей права та тому є комплексною галуззю права, що співіснує поряд з основними галузями права (цивільним, кримінальним, адміністративним, трудовим, процесуальним) і займає особливе місце в системі права $[17$, с. $27 ; 18$, с. 35]. Із нашої точки зору, представляється більш вірною позиція провідних вчених Заверухи О.Б., Запольского С.В., Ашмариної Е.М., Кучерявенко М.П. та інших [19, с. 19; 20, с. 36; 21, с. 44-62; 22, с. 179-182], згідно з якою інвестиційне право виступає підгалуззю фінансового права і одночасно на комплексному (вторинному) рівні правового регулювання може згодом сформуватися як самостійна комплексна галузь права.

Наявність ефективного механізму забезпечення державних гарантій прав суб'єктів інвестиційної діяльності та безумовності адміністративно-правового захисту їхніх фінансових вкладень виступає головною характеризуючою рисою інвестиційного клімату держави й одночасно основним визначальним фактором інвестиційної привабливості або ж непривабливості економіки відповідної держави, причому як для іноземних, так і для внутрішніх інвесторів. При цьому, крім заходів структурної економічної політики, спрямованих на забезпечення існування та сталого функціонування такої системи забезпечення державних гарантій прав суб'єктів інвестиційної діяльності та безумовності адміністративно-правового захисту їх інвестицій, найважливішим фактором є наявність розвиненої системи фінансово-правового забезпечення іноземних та внутрішніх інвестицій.

Під час розгляду інвестицій як поняття інвестиційного права слід враховувати, що: по-перше, поняття «інвестиція» використовується в ряді галузей законодавства i, отже, $є$ міжгалузевим; по-друге, це поняття законодавчо закріплено в декількох нормативних актах та його формулювання не однакові; по-третє, в юридичній науці підходи у визначенні цього поняття та формулюванні поняття інвестицій, запропоновані представниками різних підходів, відрізняються. Класифікувати їх важко, оскільки складно виділити ознаку, яку можна покласти в основу класифікації цих визначень. У рамках дослідження будуть розглядатися визначення, згруповані за способом їх застосування, тобто визначення, що знаходяться в науковому обороті, дефініції яких законодавчо закріплені. Усередині групи законодавчо закріплених визначень будуть розглянуті визначення, дані у вітчизняній нормативній базі, а також легальні визначення із правових норм зарубіжних країн. Також треба відзначити, що терміни «інвестиції» та «інвестиційна діяльність» імплементовані у правову науку з іншої галузі знань - економіки. У зв'язку із цим у ході їх вивчення неможливо ігнорувати економічний зміст, який лежить у їхній основі.

Відтак «інвестиції» - слово іноземного походження (нім. investition, від лат. investire вкладати) - довгострокове вкладання капіталу в яке-небудь підприємство, справу, особливо за кордоном, щоб отримати прибуток [23, с. 260]. Не виключено, що поняття «інвестиції» етимологічно бере початок від англійського слова in vest («в жилетку»), тобто «капіталовкладення» [24, с. 360]. Усе це дозволяє говорити про синонімічність даних термінів. Із цієї точки зору інвестиції являють собою «сукупність витрат, що реалізуються у формі довгострокового вкладення капіталу в промисловість, сільське господарство, транспорт та інші галузі народного господарства» [25, с. 126].

Метою інвестицій автори Банківської енциклопедії [25] вважають одержання підприємницького доходу, прибутку і відповідного відсотку від понесених витрат, тобто вкладеного капіталу. У свою чергу, інвестиції поділяють на фінансові (вкладення в цінні папери (акції, облігації 
та інші), які емітуються компаніями або державою, а також об’єкти тезаврації (накопичення), банківські депозити тощо) і реальні (вкладення в основний капітал і на приріст матеріально-виробничих запасів, оновлення і вдосконалення технології, модернізацію обладнання та устаткування тощо) [5, с. 15].

На даний час у сучасній економічній теорії налічується значна кількість модифікацій поняття «інвестиції», специфіка яких пояснюється традиціями різних економічних шкіл, течій, напрямків. Цілком погоджуємося з А.П. Дукою, який відзначає, «що інвестиції, які вкладають в реальний сектор національної економіки, не тільки призводять до отримання прибутку, а й забезпечують різного роду інші (економічний, енергетичну безпеку тощо) ефекти, в тому числі й соціальний ефект, а також розвиток соціальної інфраструктури» [26, с. 46]. Подібної думки додержується значна кількість науковців (І.Й. Малий, Г.П. Подшиваленко, Н.Н. Єрмошенко, Н.Н. Скворцов, Д.В. Черваньов, Л.І. Нейкова, О.Б. Кутик, О.Г. Нікольска, М.П. Бутко тощо).

Вельми цікавим є підхід до трактування інвестицій, запропонований Д.Л. Левчинським [27, с. 138]. Науковець вказує на їхню значимість у межах держави та регіону, пов'язує інвестиції із забезпеченням соціально-економічного розвитку, екологічної рівноваги та якості життя населення, отриманням економічного, соціального, екологічного та інших видів ефекту. Проте в даному визначенні не вказано на зацікавленість інвестора у вкладенні, тобто інвестиції являють собою взаємовигідні вкладення для держави, регіонів, суб'єктів підприємництва та інвесторів. Із цього приводу дуже слушним є твердження Сас Н.М., відповідно до якого інвестиції базуються на рівноцінній зацікавленості всіх рівнів національної економіки (макро-, мезо- та мікрорівня), суспільства та інвесторів. Так, Сас Н.М. пропонує інвестиціями вважати вкладення фінансових, матеріальних, інтелектуальних, інформаційних ресурсів у розвиток та відтворення окремих об'єктів, зумовлені паритетним задоволенням інтересів суспільства, учасників всіх рівнів національної економіки (макро-, мезо- та мікрорівня) та інвесторів у досягненні фінансового ефекту (для інвестора) та економічного, екологічного, соціального та інших видів ефекту (для національної економіки та суспільства) [28, с. 16].

Окремі дослідники, звертаючись до трактування інвестицій, поряд з економічними ознаками інвестицій вказують на необхідність досягнення іншого неекономічного ефекту. Так, В.В. Бочаров та Р.Г. Попова підсумовують: «Інвестиції висловлюють всі види майнових та інтелектуальних цінностей, що вкладаються в об'єкти підприємницької діяльності, в результаті яких формується прибуток (дохід) або досягається соціальний ефект» [29, с. 24]. Характерна для більшості визначень вказівка на позитивний матеріальний результат або досягнення позитивного соціального ефекту як цілі інвестування не $\epsilon$ безперечною, в тому числі й у сфері адміністративно-правового захисту інвестицій.

Безумовно, одним із головних критеріїв інвестиції є приріст капіталу. Представники такого підходу - Е. Дж. Долан та Б. І. Домненко - стверджують, що до інвестицій відносяться витрати тільки на новостворені або здобуті блага» [30, с. 184]. Більшість інших визначень також зводять процес інвестування до отримання прибутку, тобто збільшення капіталу щодо вкладеної кількості. Ці визначення розкривають глибинну проблему сучасної економічної, статистичної та правової науки - складність кількісного та якісного визначення інвестицій.

У сучасній системі обліку інвестицій як міжнародного, так і національного походження неможливо розмежувати інвестиції, які викликають приріст капіталу, а також дії суб'єктів інвестиційної діяльності, що формально підпадають під легальні визначення інвестицій, але не тягнуть прирощення капіталу.

Оскільки в повсякденній практиці під категорією інвестицій розуміється сукупність різних способів капіталовкладення у приватний сектор економіки та використання доходів із метою подальшого збільшення, придбання засобів виробництва, то, виходячи з вищесказаного, можна охарактеризувати інвестиції як будь-який можливий засіб не тільки для збільшення, але й для збереження та для адміністративно-правового захисту капіталу.

У нашій державі законодавче визначення інвестицій вперше з'явилося із прийняттям у 1991 році Закону України «Про інвестиційну діяльність», який визначив загальні правові, економічні та соціальні умови інвестиційної діяльності на території України [31]. Згідно зі ст. 1 Закону України від 18 вересня 1991 р. «Про інвестиційну діяльність» інвестиціями $є$ всі види майнових та інтелектуальних цінностей, що вкладаються в об'єкти підприємницької та інших видів діяльності, в результаті якої створюється прибуток (доход) та/або досягається соціальний та екологічний ефект. Наукова критика даного визначення розкрила ряд його недоліків, зокрема вказувалося на те, що визначення інвестицій не містить прямої вказівки на грошові кошти як 
об'єкт інвестиційних відносин [32, с. 17; 33, с. 35]. Отже, дане визначення акцентує увагу на тому, що саме вкладається (інвестиція - певна цінність, що вкладається), та на меті інвестування (отримання прибутку або соціального ефекту), не визначаючи засіб інвестування. Із нашої точки зору, таке визначення являє собою приклад обмежувального трактування поняття, оскільки в даному формулюванні законодавець постарався перерахувати всі види інвестування, хоча таке формулювання не зовсім коректне, оскільки подальший розвиток економіки незмінно призведе до виникнення його нових видів, які будуть знаходитися за межами правового регулювання. I, тим не менш, перше визначення інвестицій для цілей правового регулювання відбулося.

Отже, інвестиціями можуть бути: кошти, цільові банківські вклади, паї, акції та інші цінні папери (крім векселів); рухоме та нерухоме майно (будинки, споруди, устаткування та інші матеріальні цінності); майнові права інтелектуальної власності; сукупність технічних, технологічних, комерційних та інших знань, оформлених у вигляді технічної документації, навиків та виробничого досвіду, необхідних для організації того чи іншого виду виробництва, але не запатентованих («ноу-хау»); права користування землею, водою, ресурсами, будинками, спорудами, обладнанням, а також інші майнові права та інші цінності. Це поняття застосовується як до випадків фінансування капітальних вкладень, так і до практики їх адміністративно-правового захисту. Однак треба зауважити, що оскільки існує межа між інвестиціями та заощадженнями, то відсутнє довготермінове розміщення та систематизація цих вкладень, а перелічені цінності перетворюються на інвестиції лише тоді, коли інвестори їх вклали в об’єкти діяльності. Акції та інші цінні папери $€$ вже по суті здійсненими інвестиціями. На наш погляд, обмежувати мету інвестицій лише отриманням прибутку або досягненням соціального ефекту неправильно, тому що віддача може бути пов'язана водночас з обома цими наслідками (наприклад, утримання центрів талановитих дітей, який може одночасно приносити дохід і мати соціальний ефект).

Формулювання видів інвестицій у цьому нормативному акті, безумовно, більш вдале. По-перше, законодавець зробив спробу типізації їхніх видів i, по-друге, залишив їх список відкритим для включення знову нових видів в наявне правове поле. До числа недоліків наведених дефініцій можна віднести вказівку на вкладення перерахованих інструментів інвестування в об'єкти підприємницької та іншої діяльності. Таке формулювання явно надмірне, оскільки не несе конкретного смислового навантаження, тому що має на увазі будь-яку діяльність у тому числі економічну. Під час тлумачення цієї норми вказівка на будь-які види діяльності трактується як зайве, що говорить про недосконалість такого визначення.

У законодавстві України існує ще два легальних визначення поняття інвестиції. Так, відповідно до п. 14.1.81 Податкового кодексу (далі - ПК) України інвестиція визначається як господарська операція, яка передбачає придбання основних засобів, нематеріальних активів, корпоративних прав та/або цінних паперів в обмін на кошти або майно [34]. Отже, друге визначення акцентується на засобі інвестування (придбання, тобто лише купівля-продаж), а також на об'єкті інвестування, на тому, куди вкладається інвестиція.

Згідно зі ст. 326 Господарського кодексу (далі - ГК) України інвестиціями у сфері господарювання визнаються довгострокові вкладення різних видів майна, інтелектуальних цінностей та майнових прав в об'єкти господарської діяльності з метою одержання доходу (прибутку) або досягнення іншого соціального ефекту [35]. Під поняттям «вкладення» в даному випадку розуміється не інвестиція як матеріальний предмет, а інвестування як процес, і тому наведене поняття інвестиції не збігається з визначенням Закону України «Про інвестиційну діяльність».

Отже, аналіз визначень інвестицій, представлених у вітчизняній нормативній базі, розкриває ще одну важливу проблему українського інвестиційного законодавства, а саме: множинність різних законодавчо закріплених визначень інвестицій. Цей факт говорить про низький рівень законодавчої техніки розробників законів і, як наслідок, труднощі регулювання інвестицій органами виконавчої влади та потреби в уніфікації таких визначень.

Як відомо, реалізація інвестицій відбувається у процесі інвестиційної діяльності. У широкому сенсі під інвестиційною діяльністю розуміють господарську діяльність взагалі, як безперервний процес вкладення матеріальних та фінансових коштів для відтворення [36, с. 9]. У більш вузькому сенсі під інвестиційною діяльністю розуміється здійснення практичних дій щодо збереження та примноженню капіталу. Так, відповідно до статті 2 Закону України «Про інвестиційну діяльність» від 18.09.1991 року № 1560-XII під інвестиційною діяльністю розуміється «сукупність практичних дій громадян, юридичних осіб і держави щодо реалізації інвестицій» [31].

Наукові джерела розглядають інвестування схожим чином, маючи на увазі під ним здійснення діяльності з розміщення капіталу в об'єкти не тільки підприємницької, але й іншої діяль- 
ності, для отримання прибутку або досягнення іншого корисного результату [37, с. 43]. Ще більш вузький підхід до трактування інвестиційної діяльності зустрічається в зарубіжній науці та законодавстві, особливо це характерно для країн із системою загального права. Під нею розуміється підприємницька діяльність, спрямована на залучення вільних грошових коштів у невизначено широкого кола осіб для подальшого приміщення їх у цінні папери з метою вилучення прибутку [38, с. 371]. Відповідно до такого підходу склад суб'єктів інвестиційної діяльності обмежений професійними учасниками ринку цінних паперів, що діють на основі отриманої ліцензії.

Виходячи $з$ того, що для інвестиційної діяльності під час іiї визначення як правового поняття характерні системний порядок їі здійснення, вчинення дій у законодавчо закріплених межах, можна зробити висновок про те, що інвестиційна діяльність носить правовий характер, а їі суб'єкти здійснюють дії, що ведуть до встановлення та реалізації інвестиційних правовідносин. Правові рамки ж інвестиційної діяльності встановлюються державою у процесі її адміністративно-правового регулювання.

Інвестиційна діяльність являє собою складне, багатопланове явище. 3 одного боку, вона виступає як діяльність 3 управління державними інвестиціями, а 3 іншого - сама $є$ об'єктом управлінського впливу. Однак слід зазначити, що участь держави в інвестиційній діяльності має об'єктивні межі. Ці межі, з одного боку, зумовлені реальними фінансовими можливостями публічно-територіальних утворень, а з іншого - тим, що зростання присутності держави в економіці повинно сприяти притоку приватних інвестицій, а не їх витісненню.

У науковій літературі висловлено думку, згідно з якою інвестиційна діяльність держави являє собою різновидність фінансової діяльності, що свідчить про її фінансово-правовий характер. Погоджуючись із вищевказаною точкою зору, наведемо додаткові аргументи. Так, характерні риси фінансової діяльності держави знаходять своє відображення в інвестиційній діяльності, a саме:

1. По-перше, ознака фінансової діяльності держави виражається в обов'язковості участі публічно-правового утворення (в тому числі в особі ії уповноважених органів) та знаходить своє втілення в тому, що «держава, як учасник інвестиційної діяльності, виступаючи в якості інвестора, одночасно здійснює верховенство в межах державної території та організовує свою законодавчу, виконавчу й судову владу шляхом прийняття правових приписів» [39, с. 110].

2. По-друге, фінансова діяльність держави проявляється в акумулюванні, розподілі та використанні державних і муніципальних грошових фонд. Зазначена ознака притаманна й інвестиційній діяльності держави, оскільки державні інвестиції в економічному аспекті представляють сукупність державних ресурсів (активів, асигнувань), що підлягають розподілу на публічні цілі, і державних вкладень (використання державних ресурсів), що забезпечують створення та збільшення вартості державного майна.

3. По-третє, цільова спрямованість інвестиційної діяльності держави дозволяє зробити висновок про публічний характер ії цілей, що мають також економічні і соціальні риси (державні інвестиції завжди спрямовані на соціально-економічний та науково-технічний розвиток України).

4. По-четверте, відносини, що виникають у результаті державної інвестиційної діяльності, як і фінансової, відносяться до різновиду майнових, оскільки складаються із приводу розподілу та вкладення державних інвестицій (фінансових ресурсів).

5. По-п’яте, у фінансово-правовому регулюванні інвестиційної діяльності держави переважно використовується імперативний метод фінансового права, заснований на владних приписах учасників інвестиційних відносин за участю державних органів.

6. По-шосте, інвестиційній діяльності держави притаманний фінансовий контроль за дотриманням законності та доцільності дій у сфері реалізації інвестиційних проектів, що фінансуються повністю або частково за рахунок коштів державного бюджету України чи місцевих бюджетів, а також інших державних джерел.

Резюмуючи вищевикладене, можна зробити висновок, що інвестиційній діяльності держави притаманні основні ознаки фінансової діяльності, що зумовлює можливість ії характеристики як складової частини механізму соціального управління, спрямованого на задоволення публічних інтересів, та свідчить про можливість її регулювання нормами фінансового право.

Аналізуючи поняття «інвестиція» та «інвестиційна діяльність» як об' єкти адміністративно-правового захисту, ми прийшли до висновку, що чинне законодавство, на жаль, не містить визначень а отже, повною мірою не розкриває сутність правового захисту інвестицій та інвестиційної діяльності. На наш погляд, правовий захист інвестицій являє собою гарантовану держа- 
вою на основі законодавства про інвестиційну діяльність забезпеченість інвесторам, у тому числі іноземним, рівноправних умов діяльності, що виключають застосування заходів дискримінаційного характеру, які могли б перешкоджати управлінню та розпорядженню інвестиціями.

\section{Список використаних джерел:}

1. Хрімлі О.Г. Захист прав інвесторів у сфері господарювання: теоретико-правовий аспект : монографія / НАН України, Ін-т економіко-правових досліджень. Київ : Юрінком Інтер, 2016. $320 \mathrm{c}$.

2. Булатов К.Г. Административно-правовая защита физических и юридических лиц в Российской Федерации : дис. ... д-ра юрид. наук : 12.00.02. Москва, 1998. 349 с.

3. Олійник О.Б. Реформування юридичної риторики в Україні: євроінтеграція та адаптація національного законодавства і права України до законодавства та права Свропейського Союзу. Віче : журнал Верховної Ради Украӥни. Громадсько-політичне і теоретичне видання. Київ, 2010. № 18(279). С. 27-29.

4. Прадід Ю.Ф. Вступ до юридичної лінгвістики : навч. Посібник ; за ред. чл.-кор. АПрН О.Н. Ярмиша. Сімферополь : Доля, 2002. 104 с.

5. Качур Р.П. Державне регулювання інвестиційної діяльності в трансформаційній економіці України : дис. ... канд. юрид. наук : 08.00.03. Львів, 2015. 237 с.

6. Карпинская Е.В. Унификация, стандартизация, кодификация терминов. Понятие о гармонизации терминов и терміносистем. Культура русской речи : учебник для вузов / под ред. Л.К. Граудиной и Е.Н. Ширяева. Москва, 2003. § 27. Гл. IV. С. 207-210.

7. Туранин В.Ю. Проблемы и перспективы унификации терминологии. Журнал российского права. 2002. № 11. С. 46-48.

8. Гуревич И.С. Правовые проблемы расчетных и кредитных отношений : автореф. дис. ... д-ра юрид. наук : 12.00 .14 ; Ленингр. гос. ун-т им. А.А. Жданова. Юрид. фак. Ленинград : [б. и.], 1972. 38 с. 2010. $256 \mathrm{c}$

9. Податкове право України : навч. посіб. / за ред. М.П. Кучерявенка. Харків : Право,

10. Волощук М.Г., Карабін Т.О., Менджул М.В. Фінансове право [Текст] : навч. посіб. Вид. 3-те, допов. та перероб. Ужгород : Видавництво Олександри Гаркуші, 2017. 244 с.

11. Коммерческое право / Под ред. В.Ф. Попондопуло, В.Ф. Яковлевой. Санкт-Петербург : Издательство С.-Петербургского университета, 1998. 518 с.

12. Вінник О.М. Інвестиційне право. Київ : Атіка, 2000. 252 с. 1972. $396 \mathrm{c}$.

13. Алексеев С.С. Проблемы теории права. Курс лекций в двух томах. Т. 1. Свердловск,

14. Оніщенко Н.М. Правова система: проблеми теорії : монографія. Київ : Ін-т держави і права ім. В.М. Корецького НАН України, 2002. 352 с.

15. Мороз С.П. Принципы инвестиционного права. Журнал российского права. Москва : Норма, 2003. № 3. С. 55-61.

16. Ганьба Б. Системний підхід та його застосування в дослідженні державно-правових явищ. Право Украӥни. 2000. № 3. С. 41-44.

17. ГуткевичС. О. Стратегія розвитку: інвестиційний вимір : монографія / за ред. проф. Гуткевич С.О. Харків, 2016. 162 с.

18. Лисенкова О.С. Система законодавства України: структурно-функціональна характеристика : дис. ... канд. юрид. наук : 12.00.01. Київ, 2001. 228 с.

19. Заверуха О.Б. Бюджетні повноваження органів місцевого самоврядування в Україні : дис. ... канд. юрид. наук : 12.00.07 ; Чернівецьк. держ. ун-т ім. Ю. Федьковича. Чернівці, 2001. 223 с. 20. Запольский С.В. Дискуссионные вопросы теории финансового права : монография. Москва : РАП, Эксмо, 2008. 160 с.

21. Ашмарина Е.М. Некоторые аспекты расширения предмета финансового права в Российской Федерации: проблемы и перспективы : монография. Москва : Полиграф ОПТ, 2004. 128 с.

22. Кучерявенко М.П. Актуальні питання науки фінансового права : монографія. Харків : Право, 2010. 464 с.

23. Новий словник іншомовних слів: близько 40000 слів і словосполучень / Л.І. Шевченко, О.І. Ніка, О.І. Хом'як, А.А. Дем'янюк ; за ред. Л.І. Шевченко. Київ : АРІЙ, 2008. 672 с.

24. Сучасний тлумачний словник української мови: 100000 слів / За заг. ред. д-ра філол. наук, проф. В.В. Дубічинського. Харків : ВД «ШКОЛА», 2009. 1008 с. 
25. Банківська енциклопедія / кол. авт.: М.І. Савлук, А.М. Поддєрьогін, А.А. Пересада, Н.Д. Олексієнко та ін. ; під ред. д-ра екон. наук, проф. А.М. Мороза. Київ : «Ельтон», 1993. 328 с.

26. Дука А.П. Теорія та практика інвестиційної діяльності. Інвестування : навч. посібник. Київ : Каравела, 2007. 424 с.

27. Левчинський Д.Л. Суть та економічна природа інвестицій та інвестиційного процесу. Механізм регулювання економіки. 2011. № 2. С. 138.

28. Сас Н.М. Механзім регулювання інвестиційних процесів в національній економіці : дис. ... канд. економ. наук : 08.00.03 / Донбаська Державна Машинобудівна Академія. Краматорськ, 2016. 210 с.

29. Бочаров В.В., Попова Р.Г. Финансово-кредитный механизм регулирования инвестиционной деятельности предприятий : учеб. пособие / Санкт-Петербург. ун-т экономики и финансов, каф. финансов. Санкт-Петербург : Изд-во Санкт-Петербург. ун-та экономики и финансов, 1993. $85 \mathrm{c}$.

30. Долан Э.Д., Домненко Б.И. Economics : Англо-рус. словарь-справочник. Москва : Лазурь : Журн. «Бух. учет», 1994. 542 с.

31. Про інвестиційну діяльність : Закон України від 18.09.1991 року № 1560-XII. Вiдомості Верховної Ради Украӥни (ВВР). 1991. № 47. Ст. 646.

32. Шишка Р.Б. Инвестиционное право Украины : учеб. пособие. Харьков : Эспада, 2003. $160 \mathrm{c}$.

33. Жорнокуй Ю.М. Інвестиційне право : підручник / Схід.-регіон. центр гуманітар.-освіт. ініціатив, 2011. 192 с.

34. Податковий кодекс України : Закон України від 02.12.2010 року № 2755-VI. Вiдомості Верховної Ради України (ВВР). 2011. № 13-14, № 15-16, № 17. Ст. 112.

35. Господарський кодекс України : Закон України від 16.01.2003 року № 436-IV. Вiдомості Верховної Ради Украӥни (ВВР). 2003. № 18, № 19-20, № 21-22. Ст. 144. 1992. $272 \mathrm{c}$.

36. Богатырев А.Г. Инвестиционное право / под. ред. Рябова Л.И. Москва : Рос. право,

37. Барихин А.Б. Большая юридическая энциклопедия : более 30000 терминов и определений / 2-е изд., перераб. и доп. Москва : Книжный мир, 2010. 960 с.

38. Российская юридическая энциклопедия / Т.Е. Абова и др. ; гл. ред. А.Я. Сухарев. Москва : ИНФРА-М, 1999. 1110 с.

39. Трапезников В.А. Особенности правового статуса государства как участника инвестиционных отношений. Право и политика. Москва : Nota Bene, 2006, № 1. С. 110-119. 